\title{
STRATERGI DALAM MEWUJUDKAN KEHIDUPAN BERJELANJUTAN (SUSTAINABLE LIVELIHOOD) MASYARAKAT TEUPIN KUYUN KECAMATAN SEUNEDON KABUPATEN ACEH UTARA
}

\author{
Teuku Alfiad,S.Sos.,MSP ${ }^{1}$ Awaludin Arifin,S.I.Kom.,M.I.Kom ${ }^{2}$ dan Arinanda ${ }^{3}$ \\ 1 dan 3. Dosen Program Studi Administrasi Publik \\ 2. Dosen Program Studi Ilmu Komunikasi Universitas Malikussaleh \\ Email: teuku.alfiady@unimal.ac.id
}

\begin{abstract}
ABSTRAK
Masyarakat Teupin Kuyun secara umum bersandar pada dua sumber penghasilan, yaitu sebagai nelayan dan petani garam tradisional sebagai penopang kebutuhan hidupan mereka. Sebagai nelayan masyarakat Teupin Kuyun terkendala dengan hasil tangkapan yang tidak menentu serta kepemilikan sarana alat tangkap yang mesti mewenya kepada pihak ketiga. Sehingga hasil tangkapannya tidak dinikmati seutuhnya, mereka harus berbagi hasil dengan pihak penyewa dengan sistem bagi hasil yang tidak menguntungkan. Sebagai petani garam masyarakat juga tidak menerima pendapatan yang mencukupi. Petani garam tradisional dengan sistem perebusan yang dijalani memerlukan biaya produksi yang cukup besar. Banyak petani garam berhenti produksi, karena tidak memiliki modal yang cukup tiap kali memulai usahanya. Ketergantungan masyarakat Teupin Kuyun terhadap sumber daya alam yang teresedia menempatkan mereka pada posisi yang sulit untuk dapat mewujudkan hidup yang sejahtera. Ketersediaan sumber daya alam memiliki batas tingkat produktifitasnya serta sangat tergantung terhadap kondisi cuaca. Kajian ini memperlihatkan bahwa untuk mencapai kehidupan yang berlangsung lama diperlukan keterampilan lain oleh masyarakat setempat. Modernisasi sistem produksi garam juga perlu dilakukan untuk menekan biaya produksi yang tidak rasional. Dimana biaya produksi tidak seimbang dengan penghasilan yang didapatkan.
\end{abstract}

Kata kunci: Strategi, Kehidupan berkelanjutan, dan masyarakat

\section{Pendahuluan}

Prinsip pengelolaan sumberdaya alam diantaranya adalah bahwa pengembangan teknologi pengelola sumber daya alam harus memperhatikan keseimbangan dan kelestarian lingkungan. Keseimbangan yang dimaksud berhubungan dengan keselarasan proses pengelolaan dengan kondisi alam lingkungan sekitar lokasi sumberdaya alam. Sedangkan kelestarian tentu berkaitan dengan upaya menjaga mutu dan kualitas lingkungan sehingga proses pengelolaan sumberdaya alam yang dilakukan tidak 
menyebabkan menurunnya daya dukung lingkungan pada kehidupan makhluk hidup termasuk manusia di sekitar lokasi pengelolaan. Akan halnya pengelolaan di bidang pertambangan dan energi pencegahan kerusakan sumber alam tanah dan air sebagai akibat eksploitasi pertambangan menjadi penting sebagai upaya menjaga kelestarian alam. Sementara itu, upaya `menjaga keseimbangan memerlukan sebuah sistem manajeman yang bisa menempatkan semua komponen alam di sekitar lokasi pengelolan sebagai satu kesatuan. Ketidak nyamanan salah satu komponen lingkungan yang ada akan bisa secara langsung merusak proses pengelolaan sumber daya alam yang dilakukan.

Sesuai dengan pasal 33 Undang-undang Dasar Negara Republik Indonesia tahun 1954 pasal 3 menyebutkan bahwa Bumi, air dan kekayaan alam yang terkandung didalamnya dikuasai oleh Negara dan dipergunakan untuk sebesar-besarnya kemakmuran rakyat, dan pasal 4 berbunyi perekonomian nasional diselenggarakan berdasar atas demokrasi ekonomi dengan prinsip kebersamaan, efisiensi berkeadilan, berkelanjutan, berwawasan lingkungan, kemandirian, serta dengan menjaga keseimbangan kemajuan dan kesatuan ekonomi nasional. Inti dari kedua pasal itulah salah satunya adalah bahwa semua aktivitas ekonomi yang terkait dengan eksplorasi dan eksploitasi kekayaan sumberdaya alam harus bisa memberi dampak pada perbaikan kesejahteraan masyarakat. Dalam rangka mewujudkan kondisi tersebut, negara wajib hadir dengan ikut menjamin pelaksanaan prinsip-prinsip pengelolaan yang disyaratkan melalui undang-undang.

Sumber daya manusia di Gampong Teupin Kuyun masih tergolong rendah, meski angka putus sekolah cukup rendah yaitu 11 orang. Namun yang memiliki kualifikasi pendidikan sarjana masih sangat terbatas. Masyarakat Teupin Kuyun uumnya adalah masyarakat paternalitik, dimana keputusan masih banyak ditentukan oleh laki-laki. Perempuan umumnya mengurusi persoalan domestik, seperti mengurus.

Jurnal Jurnalisme Edisi, 1 Volume 10 April 2021 


\section{Rumusan Masalah}

Bagaiamana kebijakan yang relevan dalam mendukung kehidupan berkelanjutan pada masyarakat Teupin Kuyun Kecamatan Seunedon Kabupaten Aceh Utara provinsi Aceh.

\section{Landasan Teori}

\begin{tabular}{|c|c|}
\hline $\begin{array}{c}\text { Komponen Sustainable } \\
\text { Livelihood }\end{array}$ & Indikator \\
\hline $\begin{array}{lll}\text { Modal } & \text { Alam } & \text { (Natural } \\
\text { Capital) } & & \end{array}$ & $\begin{array}{l}\text { - Tanah dan proses produksi } \\
\text { - Air dan Sumberdaya Perairan } \\
\text { - Keanekaragam sumbedaya genetic } \\
\text { - Kayu dan Produk Kehutanan } \\
\text { - Satwa liar }\end{array}$ \\
\hline $\begin{array}{l}\text { Modal Sumberdaya Manusia } \\
\text { (Human Capital) }\end{array}$ & $\begin{array}{l}\text { - Tingkat Kesehatan } \\
\text { - Tingkat Gizi } \\
\text { - Pendidikan } \\
\text { - Pengetahuan dan Keterampilan } \\
\text { - Kemampuan Bekerja } \\
\text { - Kemampuan Beradaptasi }\end{array}$ \\
\hline $\begin{array}{l}\text { Modal Ekonomi (Economic/ } \\
\text { Financial Capital) }\end{array}$ & $\begin{array}{l}\text { - Pendapatan rata-rata/ income } \\
\text { - Tabungan } \\
\text { - Utang/ Piutang Resmi } \\
\text { - Remittence/ Putaran Uang-modal } \\
\text { - Pendapatan Pensiun }\end{array}$ \\
\hline Modal Sosial (Social Capital) & $\begin{array}{l}\text { - Koneksi dan Jaringan Kerja } \\
\text { - Hubungan saling mendukung dan saling } \\
\text { percaya } \\
\text { - Formal dan Informal Group } \\
\text { - Representasi Kolektif } \\
\text { - Mekanisme Partisipasi Pengambilan } \\
\text { Keputusan } \\
\text { - Kepemimpinan }\end{array}$ \\
\hline Modal Fisik (Pyisical Capital) & $\begin{array}{l}\text { - Infrastruktur } \\
\text { - Transportasi, Jalan dan Kendaraan/Armada } \\
\text { - Tempat Berlindung dan Bangunan } \\
\text { (Akomodasi) } \\
\text { - Suplai Air Bersih dan Sanitasi } \\
\text { - Energi } \\
\text { - Komunikasi } \\
\text { - Peralatan dan Teknologi } \\
\text { - Teknologi Tradisional }\end{array}$ \\
\hline
\end{tabular}

Jurnal Jurnalisme Edisi, 1 Volume 10 April 2021 


\section{Metode Penelitian}

kajian ini menggunakan pendekatan penelitian Kualitatif deskriptif. secara metodologis Kualitatif digunakan untuk memahami interaksi sosial serta dengan metode wawancara mendalam, maka diharapkan ditemukan pola-pola hubungan yang berkembang dan faktor-faktor yang mempengaruhi. Data penelitian ini adalah data kualitatif, yaitu data yang menunjukkan kualitas atau mutu dari suatu yang ada, berupa keadaan, proses, kejadian atau peristiwa dan lain-lain yang dinyatakan dalam bentuk perkataan (Sugiyono, 2011:28).

\section{Hasil Penelitian dan Pembahasan}

\section{Gamabaran Umum Gampong Teupin Kuyun}

Gampong Teupin Kuyun merupakan salah satu dari 33 gampong yang berada di Kecamatan Seunedon Kabupaten Aceh Utara serta berada dalam salah satu dari 12 gampong di kemukiman Pante Seuneddon. Kata Teupin sendiri pada masyarakat setempat diartikan dengan "daratan", sedangkan Kuyun dalam pada masyarakat Aceh pada umumnya merujuk pada buah jeruk nipis. masyarakat Teupin Kuyun sendiri tidak memiliki pengetahuan yang mupuni untuk menjelas maksud dari istilah tersebut. Sedangkan berdasarkan sejarahnya gampong Teupin Kuyun merupakan wilayah pemukiman kecil yang awal mulanya dihuni oleh beberapa penduduk di bibir pantai yang ditumbuhi oleh pohon bakau (bak Bangka). Menurut penuturan pemuka masyarakat setempat gampong ini awalnya bernama "Desa Puuk" dan saat ini Puuk menjadi salah satu nama dusun.

Gampong Teupin Kuyun memiliki 3 (tiga) dusun, yaitu: dusun Lancang, Puuk, dan dusun Jaya. Dengan luas wilayah 576 ha terbagi atas wilayah perumahan (180 ha), wilayah pantai (6 ha), wilayah tambak (385 ha), dan wilayah industry garam (15 ha). Gampong Teupin Kuyun pertama kali didirikan pada tahun 1955 dipimpin oleh Keuchik Husen, dilanjutkan oleh anaknya Keuchik Ubit, kemudian dilanjutkan oleh anak Keuchik Ubit, Keuchik Keuchik Abdul Wahab, dilanjutkan oleh Abdul Ghani, diteruskan oleh Abdullah, berganti menjadi Abdullah Gantoe. Pasca tsunami tahun 2004 dipimpin oleh Keuchik Kamaruddin dan hingga sampai saat dipimpin oleh 
Keuchik Saifuddin sejak tahun 2013. Saat ini merupakan priode kepemimpin Keuchik Saifuddin.

Hingga akhir 2019 Gampong Teupin Kuyun memiliki jumlah penduduk tercatat 1.070 jiwa dengan jumlah kepala keluarga (KK) 218 kepala keluarga yang tersebar di tiga dusun, yaitu dusun Jaya, Puuk, dan Lancang. Dusun Lancang dengan tingkat penduduk terbanyak yaitu 460 jiwa (43\%), kemudian dusun Jaya sebesar 306 jiwa $(28,6 \%)$ dan terakhir dusun Puuk 304 jiwa $(28,4 \%)$. Sarana pendidikan yang tersedia di gampong Teupin Kuyun hanya sarana pendidikan prasekolah, yaitu satu sarana Pendidikan Anak Usia Dini (PAUD). Sedangkan sarana pendidikan untuk jenjang lainnya tidak tersedia. Untuk menunaikan pendidikan SD peserta didik bersekolah d gampong tetangga, sedangkan sekolah menengah pertama di SMPN 3 Ulee Matang yang berjarak dua kilometer. Sedangkan untuk sekolah menengah atas di SMA Negeri I Seuneddon di Gampong Paya Dua Uram dan SMK Negeri I Seuneddon di Gampong Alue Bareuh dengan jarak $\pm 7 \mathrm{Km}$.

\section{Kehidupan Sosial Masyarakat Teupin Kuyun}

Masyarakat Teupin Kuyun merupakan masyarakat pesisir dimana kehidupan perekonomian mereka sangat bergantungan secara langsung terhadap pemanfaatan sumberdaya laut dan pesisir. Baik sebagai nelayan, petani garam, petambak dan pedagang (Toke bangku) yang menjual hasil tangkapan laut. Pekerjaan laut seperti nelayan menjadi wilayah laki-laki karena pekerjaan ini membutuhkan kekuatan fisik, berisiko tinggi, dilakukan pada siang dan malam hari, berkecepatan tinggi. Karenanya, sejauh ini belum ditemukan seorangpun nelayan di Teupin Kuyun dari kalangan perempuan. Perempuan memiliki pekerjaan di darat terutama yang berkaitan dengan urusan domestik dan rumah tangga. Sebagian perempuan juga memiliki fungsi layaknya laki-laki, bekerja untuk memenuhi kebutuhan dasar rumah tangga. Fungsinya dapat sebagai koplement (pelengkap) dari apa yang dihasilkan oleh sumai mereka, juga dapat berfungsi sebagai supplement (sumber utama) terutama perempuan yang tidak memiliki suami (janda) atau suami yang cacat permanen sehingga tidak mampu lagi mencari nafkah. 
Hampir keseluruhan nelayan dan pelaku usaha garam yang menjadi penopang utama perekonomian masyaraat Teupin Kuyun adalah nelayan dan pelaku usaha tradisional dan buruh. Teknologi penangkapan ikan sebatas pada kapal motor (boat) sedangkan peralatan untuk menangkap ikan masih menggunakan jaring manual. Teknologi produksi garam juga masih sangat tradisional dengan cara merebus, belum mengarah pada metode produksi beomembran seperti yang direncanakan dalam program Program Usaha Garam Rakyat (PuGAR) oleh kementerian KKP.

Sumber daya manusia di Gampong Teupin Kuyun masih tergolong rendah, meski angka putus sekolah cukup rendah yaitu 11 orang. Namun yang memiliki kualifikasi pendidikan sarjana masih sangat terbatas. Masyarakat Teupin Kuyun uumnya adalah masyarakat paternalitik, dimana keputusan masih banyak ditentukan oleh laki-laki. Perempuan umumnya mengurusi persoalan domestik, seperti mengurus anak, pekerjaan rumah. Kondisi seperti ini pada satu sisi menguntungkan bagi pembangunan gampong untuk mendorong pembangunan yang partisipatif. Secara umum masyarakat Teupin Kuyun adalah masyarakat terbuka, dan taat terhadap agama (Islam). Masyarakat Teupin Kuyun terlibat aktif dalam perayaan hari-hari besar agama, dan ritual-ritual keagamaan dan pagelaran kebudayaan secara rutin. Seperti grup zikir, kendri laut, peringatan mauled, isra' mi'raj, kenduri udep, kenduri mate dan sebagainya

Hasil penjajakan data melalui penjajakan terhadap beberapa dokumen relevan terutama data observasi dan kuisioner yang disebar luaskan menjelaskan kondisi sosial yang dihadapi oleh masyarakat Teupin Kuyun terlihat bahwa permasalahan kemiskinan merupakan masalah terbesar yang dihadapai dimana dari 218 kepala keluarga yang dijadikan sebagai responden 215 diantaranya memilih kemiskinan sebagai masalah sosial. Tindakan pidana criminal seperti pencurian, narkoba dan kenakalan remaja bukan persoalan utama masyarakat.

Tabel: Masalah Sosial Di Teupin Kuyun

\begin{tabular}{|l|c|c|c|c|c|c|c|c|c|c|}
\hline \multirow{2}{*}{ Dusun } & \multicolumn{2}{|c|}{$\begin{array}{c}\text { Kemiskina } \\
n\end{array}$} & \multicolumn{2}{|c|}{ Pencurian } & \multicolumn{2}{c|}{ Narkoba } & \multicolumn{2}{c|}{$\begin{array}{c}\text { Kenakalan } \\
\text { Remaja }\end{array}$} & \multirow{2}{*}{ Total } \\
\cline { 2 - 10 } & iya & iya & Iya & Tidak & Iya & $\begin{array}{c}\text { Tida } \\
\mathrm{k}\end{array}$ & lya & Tidak & \\
\hline Dusun Jaya & 59 & 0 & 18 & 41 & 7 & 52 & 3 & 56 & 59 \\
\hline Dusun Lancang & 102 & 1 & 31 & 72 & 23 & 80 & 4 & 99 & 103 \\
\hline
\end{tabular}

Jurnal Jurnalisme Edisi, 1 Volume 10 April 2021 


\begin{tabular}{|l|c|c|c|c|c|c|c|c|c|}
\hline Dusun Pu'uk & 54 & 2 & 19 & 37 & 4 & 52 & 1 & 55 & 56 \\
\hline Total & 215 & 3 & 68 & 150 & 34 & 184 & 8 & 210 & 218 \\
\hline
\end{tabular}

Sumber: Diolah dari beberapa sumber, 2020

\section{Kondisi Perekonomian Masyarakat Teupin Kuyun}

Mayoritas mata pencaharian masyarakat gampong Teupin Kuyun adalah nelayan dan petani. Perkembangan perekonomian ini juga dipengaruhi oleh topografi wilayah yang sebagian besar adalah wilayah tambak (385 ha), wilayah industri garam (15 ha), dan wilayah pantai (6 ha). Tingkat pendidikan masyarakat yang rata-rata hanya sampai pada sekolah lanjutan tingkat pertama dan tingkat atas (SLTP/SLTA) ikut berpengaruh pada peran mereka dalam dunia kerja. Angka pengangguran yang relatif tinggi (mencapai angka 60\%) ikut berpengaruh pada kesejahteraan gampong.

Dari hasil kajian awal tim lapangan, maka ditemukan beberapa jenis usaha yang mendukung perekonomian masyarakat gampong Teupin Kuyun serta kondisinya hingga saat ini. Pertanian, perikanan, perkebunan, perdagangan, juga peternakan adalah sejumlah jenis usaha lain yang dijalankan masyarakatnya selain daripada pekerjaan mayoritas; nelayan. Secara teknis, ada yang dijalankan secara berkelompok dan juga ada yang dijalankan secara individu. Pun demikian dengan status kepemilikan lahan, ada yang milik pribadi dan ada yang menyewa tanah/lahan orang lain. Saat ini, ada beberapa kelompok usaha yang tidak lagi berjalan karena berbagai faktor dan alasan yang akan dijelaskan di bab berikutnya. Untuk lebih jelasnya, bisa perhatikan tabel berikut ini:

Tabel Jenis Usaha Ekonomi dan Perkembangannya di Gampong Teupin Kuyun

\begin{tabular}{|c|c|c|c|c|}
\hline No & Usaha & Jenis & Mekanisme & $\begin{array}{c}\text { Kondisi } \\
\text { Eksisting }\end{array}$ \\
\hline \multirow{2}{*}{1} & \multirow{2}{*}{ Nelayan } & Laut & $\begin{array}{c}\text { Individu dan } \\
\text { kelompok }\end{array}$ & Masih berjalan \\
\cline { 3 - 5 } & & $\begin{array}{c}\text { Sungai (mencari tiram, } \\
\text { kepiting, dan ikan) }\end{array}$ & Individu & Masih berjalan \\
\hline \multirow{2}{*}{2} & \multirow{2}{*}{ Pertanian } & Garam & $\begin{array}{c}\text { Individu dan } \\
\text { kelompok }\end{array}$ & Masih berjalan \\
\cline { 3 - 5 } & & Sawah & Individu & Masih berjalan \\
\cline { 3 - 5 } & & Palawija & Individu & Masih berjalan \\
\hline 3 & Perikanan & Tambak & Individu & Ada yang \\
\hline
\end{tabular}

Jurnal Jurnalisme Edisi, 1 Volume 10 April 2021 


\begin{tabular}{|c|c|c|c|c|}
\hline & & & & $\begin{array}{c}\text { masih berjalan } \\
\text { dan ada yang } \\
\text { sudah tidak } \\
\text { aktif lagi }\end{array}$ \\
\hline 4 & Perkebunan & Kelapa sawit & $\begin{array}{c}\text { Individu } \\
\text { (bekerja di } \\
\text { kebun orang } \\
\text { lain) }\end{array}$ & Aktif \\
\hline \multirow{5}{*}{5} & \multirow{5}{*}{ Perdagangan } & Kue basah & individu & Masih aktif \\
\hline & & Kerupuk Udang & kelompok & $\begin{array}{c}\text { Sudah tidak } \\
\text { aktif }\end{array}$ \\
\hline & & Kelontong & individu & Masih aktif \\
\hline & & Kios kecil & individu & Masih aktif \\
\hline & & Produksi Ikan Asin & Kelompok & Tidak aktif lagi \\
\hline 6 & Menjahit & Pakaian & Kelompok & Tidak lagi aktif \\
\hline 7 & Peternakan & $\begin{array}{l}\text { Kerbau, sapi dan } \\
\text { kambing }\end{array}$ & individu & Aktif \\
\hline \multirow{2}{*}{8} & \multirow{2}{*}{ Menjahit } & \multirow{2}{*}{ Pakaian } & Kelompok & Tidak Aktif \\
\hline & & & individu & Aktif \\
\hline 9 & $\begin{array}{c}\text { Bidang jasa dan } \\
\text { lainnya }\end{array}$ & Tukang bangunan & individu & Aktif \\
\hline
\end{tabular}

Sumber: diolah dari hasil wawancara, observasi dan dokumen, 2020

Beragam jenis usaha yang terdapat pada tabel di atas juga dapat dibedakan berdasarkan kelompok gender laki-laki dan perempuan. Misalnya, untuk profesi nelayan sungai (mencari kepiting dengan alat tangkap bubu, mencari tiram dan sejenisnya) kebanyakan dilakukan oleh kelompok perempuan. Biasanya, mereka menghasilkan Rp. 30.000 sampai Rp. 50.000 per harinya. Sementara nelayan laut dilakoni oleh kelompok gender laki-laki.

Pekerjaan yang dijalankan secara berkelompok, ada bebrapa yang masih aktif dan beberapa sudah tidak aktif lagi. Banyak faktor yang kemudian menjadikan usaha tersebut tenggelam di telan zaman. Misal pada usaha kerupuk udang yang tokoh sentral penggerak usaha tersebut sudah berhijrah ke negara Malaysia. Pun demikian pada kelompok menjahit yang diketuai oleh Buk Zainabon kini sudah tidak aktif lagi dikarenakan ada beberapa perbedaan pendapat di kalangan antar kelompok. 
Untuk usaha petani garam, sebagian besar mereka bekerja di lahan (lancang) garam milik orang lain, bukan milik pribadi dengan sistem bagi hasil. Untuk saat ini, modal produksi garam yang dikeluarkan terkadang tidak sesuai dengan hasil yang didapat. Modal yang dikeluarkan untuk membeli bahan baku lebih besar, terlebih lagi untuk mendapatkan bibit garam yang berkualitas harus didatangkan dari luar daerah. Sistem pemasaran yang belum terfokus juga menjadi permasalahan tersendiri untuk petani garam. Biasanya, target pasar adalah wilayah Aceh Utara, namun karena harus dijual dengan harga yang tidak kompetitif, maka peminat untuk garam teupin kuyun menurun.

\section{Kebijakan Untuk Kehidupan Berkelanjutan Pada Masyarakat Gampong Teupin Kuyun}

Berdasarkan data Observasi, FGD dan quetioner dilapangan ditemukan sejumlah bentuk modal di Gampong Teupin Kuyun yang mendukung proses penghidupan berkelanjutan bagi masyarakat. Pertama, modal alam (natural capital). Sumber daya alam merupakan modal penting karena ia bisa digunakan, digarap dan dimanfaatkan oleh masyarakat sebagai sumber pendapatan. Di gampong Teupin Kuyun, sumber daya alam yang berhasil diidentifikasi adalah lahan industri garam yang luas, wilayah pantai, ketersediaan lahan tambak yang juga sangat luas, dan juga ketersediaan lahan sawit. Akan tetapi, dari beberapa sumber daya alam tersebut, yang banyak dimanfaatkan saat ini hanya lahan industri garam dan lahan tambak. Untuk tambak, beberapa masyarakat ingin mengalihfungsikannya menjadi lahan pertanian bersebab menurut mereka tambak saat ini sudah sangat tidak produktif lagi.

Kedua, sumber daya manusia. Usia produktif merupakan fase penting dalam kehidupan seseorang. Di kedua gampong lokasi kajian, angka usia produktif warganya lumayan tinggi, di Teupin Kuyun mencapai 50\% Walaupun di gampong tersebut tingkat pendidikan formal masih terbilang rendah, namun pengetahuan-pengetahuan dasar yang berkaitan dengan pengolahan sistem sumber daya yang mereka miliki dapat diaplikasikan sebagai hasil pewarisan dari generasi sebelumnya. Sikap open minded dan kemampuan beradaptasi yang ditunjukkan warganya saat tim melakukan survey tentu juga menjadi potensi penting untuk mendukung keberlangsungan hidup.

Jurnal Jurnalisme Edisi, 1 Volume 10 April 2021 
Ketiga, modal keuangan. Keberadaan dana gampong yang dikucurkan pemerintah saat ini sebenarnya cukup membantu untuk mendorong percepatan pertumbuhan perekonomian masyarakat. Hal ini tentunya menjadi modal dalam pembangunan infrastruktur dan pengembangan masyarakat gampong. Berdasarkan data yang diperoleh dari kajian lapangan di kedua gampong tersebut menunjukkan bahwa modal keuangan gampong selain dari hasil usaha warganya, juga terdapat simpan pinjam gampong yang dijalankan melalui BUMG. Sebagian besar pekerjaan masyarakat di gampong tersebut adalah nelayan. Artinya, hasil tangkapan laut dan hasil tambak menjadi sumber perekonomian utama bagi mereka.

Keempat, modal sosial (social modal). Ada nilai-nilai yang masih sangat dijunjung tinggi oleh masyarakat gampong Teupin Kuyun. Nilai kolektifitas ini kemudian bisa dimanfaatkan guna menunjang keberlangsungan hidup masyarakat umum. "Ureung Aceh, nyoe kameupakat, lampoh jrat geutem peugala". Ungkapan ini menyiratkan dimensi kolektivitas yang terbangun dalam masyarakatnya. Nilai-nilai kolektivitas terlihat dalam aktivitas dan relasi-relasi sosial yang terajut.

Ada kebiasaan kumpul bersama dalam masyarakat. Warung kopi dan tempat ibadah (masjid dan meunasah) adalah dua ruang publik utama tempat masyarakat berkumpul. Kegiatan "ngopi bersama" menjadi media untuk membahas isu-isu hangat yang sedang berkembang, sekaligus menjadi ruang bertukar ide dan informasi. Demikian juga dengan masjid atau meunasah. Selain untuk melaksanakan salat, ia kerap dijadikan tempat bermusyawarah warga. Kemudian, cerminan kolektivitas juga dapat dilihat dalam kegiatan ketika mensukseskan acara kenduri, baik itu khanduri udeep maupun khanduri matee. Khanduri udeep adalah kenduri yang dilaksanakan sebagai bentuk rasa syukur ketika mendapatkan kebaikan atau kenikmatan, misalnya pesta perkawinan, aqiqah, dan sejenisnya. Sementara khanduri matee adalah kenduri yang dilaksanakan ketika mendapat musibah.

Selain itu, keberadaan organisasi atau lembaga baik formal seperti PKK, maupun informal di gampong seperti Lembaga Adat, kelompok takziyah, kelompok majlis taklim, dan sebagainya di kedua gampong tersebut menjadi wadah bagi 
masyarakat untuk berkumpul, berkomunikasi dan bertukar ide satu dengan lainnya sehingga hubungan kekeluargaan di masyarakat dapat terjaga.

Dan kelima adalah modal fisik (physical modal). Hasil kajian lapangan menunjukkan bahwa dari segi infrastruktur sudah bisa dikatakan memadai untuk kedua lokasi kajian. Jalan utama gampong sudah beraspal, walau ada masih di bebrapa titik yang belum tersentuh aspal. Misal di gampong Teupin Kuyun. Sarana olahraga juga tersedia, walau masih belum memadai. Di masing-masing gampong juga terdapat balai pengajian yang menjadi tempat untuk menyemai generasi berilmu. Artinya, keberadaan modal fisik ini juga ikut mendukung berkembangnya modal sumber daya manusia.

\section{Kesimpulan}

Terdapat beberapa modal yang dimiliki oleh masyarakat Teupin Kuyun dalam mendorong kehidupan berkelanjutan. Pertama Modal Alam (natural capital) yang berupa aset alam dan jasa ekosistem yang dimiliki oleh masyarakat yang dapat digunakan untuk menunjang keberlangsungan hidup. Modal alam yang tedapat di Gampong tersebut ialah kawasan pesisir yang dapat dijadikan sebagai sumber penghasilan baik sebagai petani tambak ikan maupun udang, sebagai nelayan dan petani garam tradisional. Kedua Modal sumber daya manusia (human capital) yang mencakup Keterampilan, pengetahuan, kemampuan untuk bekerja, kesehatan yang baik, kemampuan fisik yang prima dan aspek lainnya yang menunjang kehidupan. Ketiga, Modal Keuangan (ekonomic/ financial capital), yang berupa modal, baik itu dalam bentuk cash, credit, tabungan dan aset ekonomi lainnya termasuk infrastruktur dasar dan alat produksi serta teknologi yang esensial untuk mendukung kehidupan. Keempat, Modal sosial (social capital), yang berupa sumberdaya sosial, baik itu dalam bentuk jaringan sosial, klaim sosial, relasi sosial, afiliasi, asosiasi, dan sejenisnya yang diperlukan untuk menunjang kehidupan. Kelima, Modal fisik (Pyiscal Capital), yang berupa sumberdaya infrastruktur atau hasil dari produksi yang cenderung berupa materi yang dapat menunjang kehidupan masyarakat.

Jurnal Jurnalisme Edisi, 1 Volume 10 April 2021 


\section{DAFTAR PUSTAKA}

Bungin. (2009). Penelitian Kualitatif : Komunikasi, Ekonomi, Kebijakan Publik, dan Ilmu Sosial. Jakarta : Kencana Prenada Media Group.

Gabriel Almond dan Bingham Powell, Comparative Politics a Developmental

Approach, Boston: Little Brown, 1966.

Idrus. (2009). Metode Penelitian Ilmu Sosial. Yogyakarta : PT. Gelora Akasara

Pratama

Saverin \& Tankard dalam Communication Theories: Origins, Methods, Uses (1979), mencatat bahwa tahun 1910-1980,

Sutopo. (2002). Metodelogi Penelitian Kualitatif. Surakarta: Sebelas Maret University Press. 